\title{
Sweet proteins - Potential replacement for artificial low calorie sweeteners
} Ravi Kant*

\author{
Address: Institute of Bioinformatics and Applied Biotechnology, ITPL, Bangalore-560066, India \\ Email: Ravi Kant* - kravi@ibab.ac.in \\ * Corresponding author
}

Published: 09 February 2005

Nutrition Journal 2005, 4:5 doi:10.1/86/1475-289/-4-5

This article is available from: http://www.nutritionj.com/content/4/I/5

(c) 2005 Kant; licensee BioMed Central Ltd.

This is an Open Access article distributed under the terms of the Creative Commons Attribution License (http://creativecommons.org/licenses/by/2.0), which permits unrestricted use, distribution, and reproduction in any medium, provided the original work is properly cited.
Received: 01 December 2004

Accepted: 09 February 2005

\begin{abstract}
Exponential growth in the number of patients suffering from diseases caused by the consumption of sugar has become a threat to mankind's health. Artificial low calorie sweeteners available in the market may have severe side effects. It takes time to figure out the long term side effects and by the time these are established, they are replaced by a new low calorie sweetener. Saccharine has been used for centuries to sweeten foods and beverages without calories or carbohydrate. It was also used on a large scale during the sugar shortage of the two world wars but was abandoned as soon as it was linked with development of bladder cancer. Naturally occurring sweet and taste modifying proteins are being seen as potential replacements for the currently available artificial low calorie sweeteners. Interaction aspects of sweet proteins and the human sweet taste receptor are being investigated.
\end{abstract}

\section{Sweet and taste modifying proteins}

The prevalence of obesity and diabetes has increased dramatically in recent years in the United States, with similar patterns seen in several other countries including India [1] as well. Diabetes mellitus is a chronic disease caused by inherited or acquired deficiency in production of insulin by the pancreas or by the ineffectiveness of the insulin produced [2]. Artificial sweeteners like Saccharin, Aspartame, Cyclamate and AcesulfameK are used world-wide as low calorie sweeteners by patients affected by diseases linked to the consumption of sugar, e.g. diabetes, hyperlipemia, caries, obesity etc. but they have side effects such as psychological problems, mental disorders, bladder cancer, heart failure and brain tumors [3-7]. Sweet proteins have the potential to replace these artificial sweeteners, by acting as natural, good, low calorie sweeteners, as we know that proteins do not trigger a demand for insulin in these patients whereas sucrose does.

In humans, the sweet taste is mainly due to the recently discovered T1R2-T1R3 receptor [8-10], two of the three members of the T1R class [8-10] of taste-specific proteins hypothesized to function in combination as a heterodimer. The human T1R2-T1R3 receptor recognizes natural and synthetic sweetness and T1R1-T1R3 recognizes umami taste $[11,12]$. So far there are seven known sweet and taste-modifying proteins, namely Brazzein [13], Thaumatin [14], Monelin [15], Curculin [16], Mabinlin [17], Miraculin [18] and Pentadin [19]. Properties and characteristics of these proteins are illustrated in Table 1. The key residues on the protein surface responsible for biological activity have not yet been identified with 
Table I: Comparison of thaumatin, monellin, mabinlin, pentadin, brazzein, curculin and miraculin.

\begin{tabular}{|c|c|c|c|c|c|c|c|}
\hline & Thaumatin & Monellin & Mabinlin & Pentadin & Brazzein & Curculin & Miraculin \\
\hline Source & $\begin{array}{l}\text { Thaumatococcus } \\
\text { danielli Benth }\end{array}$ & $\begin{array}{l}\text { Dioscoreophyllum } \\
\text { cumminsii Diels }\end{array}$ & $\begin{array}{l}\text { Capparis } \\
\text { masakai Levl }\end{array}$ & $\begin{array}{l}\text { Pentadiplandra } \\
\text { brazzeana } \\
\text { Baillon }\end{array}$ & $\begin{array}{l}\text { Pentadiplandra } \\
\text { brazzeana } \\
\text { Baillon }\end{array}$ & $\begin{array}{l}\text { Curculingo } \\
\text { latifolia }\end{array}$ & $\begin{array}{l}\text { Richadella } \\
\text { dulcifica }\end{array}$ \\
\hline $\begin{array}{l}\text { Geographic } \\
\text { distribution }\end{array}$ & West Africa & West Africa & China & West Africa & West Africa & Malaysia & West Africa \\
\hline Variants & $\mathrm{I}, \mathrm{II}, \mathrm{a}, \mathrm{b}, \mathrm{c}^{\mathrm{a}}$ & - & I, II- a, III, IVa & - & - & - & - \\
\hline $\begin{array}{l}\text { Sweetness factor } \\
\text { (weight basis) }\end{array}$ & 3000 & 3000 & 100 & 500 & 2000 & 550 & - \\
\hline $\begin{array}{l}\text { Molecular mass } \\
\text { (active form, kDa) }\end{array}$ & 22.2 & 10.7 & 12.4 & $12.0^{\mathrm{b}}$ & 6.5 & 24.9 & 98.4 \\
\hline Amino acids & 207 & $\begin{array}{l}45 \text { (A chain) } \\
50 \text { (B chain) }\end{array}$ & $\begin{array}{l}33 \text { (A chain) } \\
72 \text { (B chain) }\end{array}$ & $?$ & 54 & 114 & 191 \\
\hline Active form & Monomer & $\operatorname{Dimer}(A+B)$ & $\operatorname{Dimer}(A+B)$ & $?$ & Monomer & $\begin{array}{l}\text { Dimer }(A+ \\
\text { A) }\end{array}$ & $\begin{array}{l}\text { Tetramer } \\
(A+A+A+A)\end{array}$ \\
\hline
\end{tabular}

Source: Adapted from Kurihara (1994). aAt least five different forms of thaumatin (Lee et al., 1988) and four different forms of mabinlin (Nirasawa et al., 1994) have been identified. bA chromatographic fraction containing a I2-kDa protein was sweet. This same fraction, when subjected to electrophoresis under non-reducing conditions showed bands in the region between 22 and $4 \mathrm{l} \mathrm{kDa,} \mathrm{suggesting} \mathrm{the} \mathrm{presence} \mathrm{of} \mathrm{subunits.}$

certainty for any of these proteins [20]. Monellin was found to be 100000 times sweeter than sucrose on a molar basis [21], followed by Brazzein and Thaumatin which are 500 times [13] and 3000 times sweeter then sucrose [14] respectively (the latter two on a weight basis). All of these proteins have been isolated from plants that grow in tropical rainforests. Although most of them share no sequence homology or structural similarity, Thaumatin shares extensive homology with certain non-sweet proteins found in other plants [15].

The potential industrial applications of these proteins are the low calorie sweetener industry and the cola, snacks, food and chocolate industries.

\section{Brazzein}

Brazzein is the smallest, most heat-stable [13] and pH-stable member of the set of proteins known to have intrinsic sweetness. The protein, consisting of 54 amino acid residues, is reported to be between 500 and 2000 times sweeter than sucrose [22] and represents an excellent alternative to available low calorie sweeteners. It was originally isolated from the fruit of an African plant Pentadiplandra brazzeana Baillon [23]. Heat and $\mathrm{pH}$ stability of the protein make it an ideal system for investigating the chemical and structural requirements of a sweet-tasting protein. Based on the wild-type brazzein, 25 mutants were produced to identify critical regions important for sweetness. To assess their sweetness, psychophysical experiments were carried out with 14 human subjects. First, the results suggest that residues 29-33 and 39-43, plus residue 36 between these stretches, as well as the C-terminus are involved in the sweetness [24]. Second, charge plays an important role in its interaction with the sweet taste receptor [24].

\section{Thaumatin}

The thaumatins are a class of intensely sweet proteins isolated from the fruit of the tropical plant Thaumatococcus danielli. The protein crystallizes in a hexagonal lattice after a temperature shift from 293 to $277 \mathrm{~K}$. The structure has been solved at $1.6 \AA$ resolution. Its fold was found to be identical to that found in three other crystal forms grown in the presence of crystallizing agents of differing chemical natures [25]. It consists of 207 amino acid residues with eight intramolecular disulfide bonds and contains no free cysteine residues. It aggregates upon heating at $\mathrm{pH}$ 7.0 above 70 degrees $C$, whereupon its sweetness disappears $[26,27]$. The protein is approximately 10000 times sweeter than sugar on a molar basis [28]. It is a protein that tastes intensely sweet only to Old World monkeys and to higher primates, including man [29], as it has been found that the protein binds to certain elements in taste pores of Rhesus monkey foliate papillae [30]. Thaumatin has been approved for use in many countries as both a flavor enhancer and a high-intensity sweetener [31].

\section{Monellin}

Monellin, a sweet protein, consists of two noncovalently associated polypeptide chains, an A chain of 44 amino acid residues and $\mathrm{a} B$ chain of 50 amino acid residues [32]. The protein can be purified from the fruit of Dioscoreophyllum cumminsii grown in West Africa and is approximately 100,000 times sweeter than sugar on a molar basis and several thousand times sweeter on a weight basis [28]. Single-chain monellin (SCM), which is an engineered 94-residue polypeptide, has proven to be as sweet as native two- 
chain monellin, and is more stable than the native monellin at high temperature and in acidic environments [33]. Native monellin is relatively sensitive to heat or acid treatment, which may cause separation of the sub-units and denaturation of the protein. Despite misgivings about the stability of the protein to heat and acid, downstream processes have been established. Its D-enantiomer has been crystallized and analyzed by X-ray crystallography at $1.8 \AA$ resolution. Two crystal forms (I and II) were found under crystallization conditions similar, but not identical, to the crystallization conditions of natural L-monellin [34]. One NMR study of a non-sweet analog in which the Asp ${ }^{\mathrm{B} 7}$ of protein was replaced by $\mathrm{Abu}^{\mathrm{B} 7}$ (L-2-Aminobutylicacid), showed similar 3-dimensional structures of these two proteins, indicating that the lack of the beta-carboxyl group in the $\mathrm{Abu}^{\mathrm{B} 7}$ analog is responsible for the loss of sweetness [35]. Recent research on identifying binding sites on the receptor by means of structure-taste relationships, found that four monellin analogues, [AsnA16]-, [AsnA22]-, [GlnA25]-, and [AsnA26]-monellin were 7500, 750, 2500, and 5500 times as sweet as sucrose on a weight basis, respectively. Thus, among them, [AsnA22]-monellin and [GlnA25]-monellin were less sweet than the native monellin [36].

\section{Curculin}

Curculin which is extracted from Curculigo latifolia acts as a good low calorie sweetener. Its maximum sweetness is equal to $0.35 \mathrm{M}$ of sucrose. It has taste modifying abilities since water and sour substances elicit a sweet taste after consumption of curculin [37]. There is no other protein currently available with both sweet taste and taste modifying abilities [38]. The taste modifying activity of the protein (discussed below) remains unchanged when it is incubated at $50^{\circ} \mathrm{C}$ for $1 \mathrm{hr}$ between $\mathrm{pH} 3$ and 11 [39].

The molecular weight of Curculin was determined by low angle laser light scattering and was found to be 27800 [38]. Its three-dimensional model has been built from the X-ray coordinates of GNA, a mannose-binding lectin from snowdrop (Galanthus nivalis) [38]. The three mannosebinding sites present in GNA were found in curculin but were not functional. Some well exposed regions on the surface of the three-dimensional model of the said protein could act as epitopes responsible for the sweet-tasting properties of the protein [40]. The protein can be crystallized by the vapor diffusion method using polyethylene glycol 400 as a precipitant. The crystals belong to orthorhombic space group P2(1)2(1)2(1) with unit cell dimensions: $\mathrm{a}=105 \AA, \mathrm{b}=271 \AA, \mathrm{c}=48.7 \AA$. The crystals diffract X-rays to resolution of $3.0 \AA$ and are suitable for Xray crystallographic studies [41].

\section{Mabinlin}

Mabinlin is a sweet protein with the highest known thermostablility [42]. It is derived from Capparis masaikai and its sweetness was estimated to be around 400 times that of sucrose on weight basis. It consists of an A chain with 33 amino acid residues and a $B$ chain composed of 72 residues. The B chain contains two intramolecular disulfide bonds and is connected to the A chain through two intermolecular disulfide bridges [43]. Its heat stability is due to the presence of these four disulfide bridges [44]. The sweetness of Mabinlin-2 is unchanged after $48 \mathrm{hr}$ incubation at boiling point [17] and of Mabinlin-3 and -4 are unchanged after $1 \mathrm{hr}$ at $80^{\circ} \mathrm{C}$ [45].

\section{Miraculin}

Miraculin is a taste-modifying protein that belongs to the class of sweet proteins. It is extracted from Richadella dulcifica an evergreen shrub native of West Africa. The protein is a single polypeptide with 191 amino acid residues [46]. It modifies the sweet receptor in such a way that it can be stimulated by acid [47]. Thus, miraculin has the unusual property of modifying sour taste into sweet taste [46].

Taste-modifying protein modifies the sweet taste receptor on binding and this behavior of these proteins is responsible for modification in taste of sour substance $[46,47]$. All acids (which are normally sour) taste sweet after consumption of these proteins. The effects of these proteins exist for around half an hour after consumption and intake of any sour substance will therefore taste sweet during this period of time. The taste buds come to there normal state with time.

\section{Pentadin}

Pentadin is a sweet protein extracted from the plant Pentadiplandra brazzeana, a shrub found in tropical forests of a few African countries. Not much information is available about the protein despite its isolation several years ago, in 1989 [48]. The protein was reported to be around 500 times sweeter then sucrose on a weight basis. It also consists of subunits coupled by disulfide bonds [49].

\section{Interaction of sweet proteins with their receptor} Humans detect taste with taste receptor cells. These are clustered in taste buds. Each taste bud has a pore that opens out to the surface of the tongue enabling molecules and ions taken into the mouth to reach the receptor cells inside. There are five primary taste sensations salty, sour, sweet, bitter and umami. Sweet and umami (the taste of monosodium glutamate) are the main pleasant tastes in humans. T1Rs are mammalian taste receptors that assemble two heteromeric G-protein-coupled receptor complexes T1R1+T1R3, an umami sensor, and T1R2+T1R3, a sweet receptor [50]. 


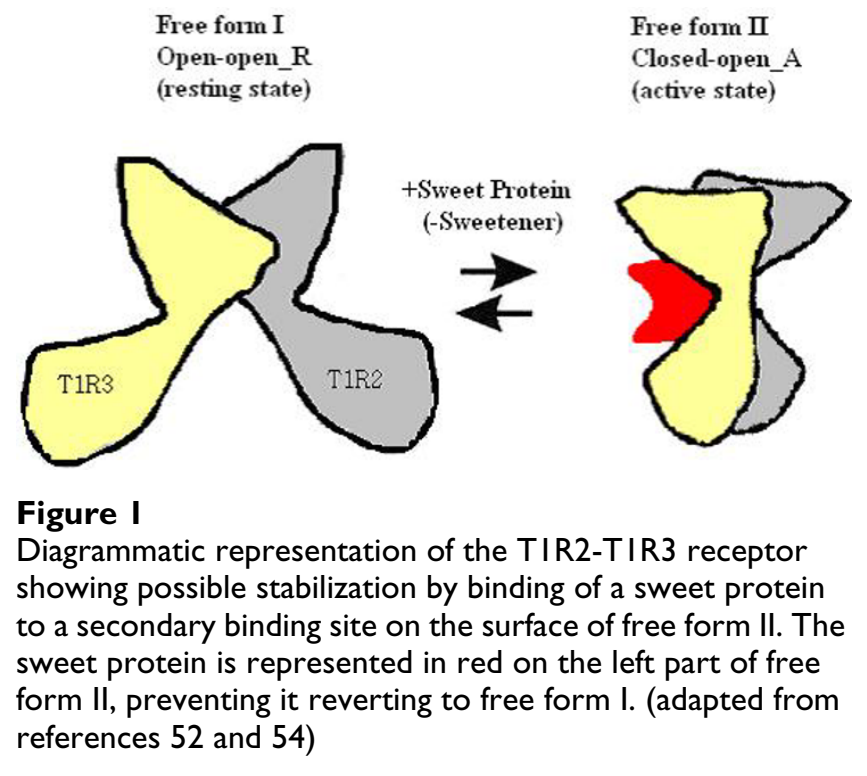

Sweet and taste-modifying proteins interact with the T1R2-T1R3 receptor with a different mechanism compared to small molecular weight compounds [51]. Recently, it has been shown that the T1R2-T1R3 receptor has many characteristics similar to the mGluR [52], apart from some minor differences in the active site region.

The major work by Kunishima et al. [52] solving the crystal structure of the N-terminal active site region of the subtype 1 of mGluR both free and complexed with glutamate has helped a lot in understanding the mechanism of interaction between ligand and T1R2-T1R3 receptor. Their structural work on mGluR and its N-terminal domain $[52,53]$ showing considerable conformational change induced by the glutamate complexation. The 'Active' and 'resting' conformations of m1-LBR, an extracellular ligand binding region of mGluR, is modulated by the dimer interface. The protomer can form 'open' or 'closed' confirmations and is made up of two domains namely LB1 and LB2. The population of active conformers depends on ligand binding, i.e. the so called 'closed-open_A'. The ligandfree receptor exists as two different structures, free form I (open-open_R), the 'resting' conformation with two open protomers and free form II (closed-open_A), nearly identical to the complexed form (Figure 1, references 52, 54). The mechanism suggested by these structures is that the receptor is in dynamic equilibrium, and that ligand binding stabilizes the 'active' dimer. There are thus two ways, in principle, to activate the receptor: first, to complexate form I with the proper ligand (glutamate for the mGluR, aspartame or any other small molecular weight sweetener for the T1R2-T1R3 receptor) and second, by shift the equi- librium between free form I and free form II in favor of free form II.

The exact mechanism of interaction of sweet proteins with the T1R2-T1R3 sweet taste receptor has not yet been elucidated [51]. Low molecular mass sweeteners and sweet proteins interact with the same receptor, the human T1R2T1R3 receptor[52]. Studies have shown that the T1R3 receptor protein is encoded by the Tas $1 \mathrm{r} 3$ gene involved in transduction of sweet taste [55].

Recently it has been found that T1R3-independent sweetand umami-responsive receptors and/or pathways also exist in taste cells [56].

\section{Conclusion and scope of further work}

As it has been found that sweet proteins are thousands of times sweeter than sucrose and are of low calorie value, these proteins can be used as natural low calorie sweeteners by people suffering from diseases linked to consumption of sugar e.g. obesity, diabetes and hyperlipemia.

Candidate proteins can be checked for biological activity with the human taste receptor. Also mutations can be induced in candidate sweet proteins to analyze changes in their physical, chemical and biological properties. The work can be taken forward by solving the structures of the proteins and taste receptors with a view to increasing the efficiency of these sweeteners.

\section{Acknowledgments}

I would like to thank Prof. S. Ramakumar, Chairman, Bioinformatics Center, Indian Institute of Science, Bangalore for useful discussions and valuable suggestions. Access to the Bioinformatics Centre and other facilities funded by the Department of Biotechnology (DBT) is gratefully acknowledged.

Also, Dr. Gayatri Saberwal, Institute of Bioinformatics and Applied Biotechnology, Bangalore for her support in writing the paper. Sincere thanks to Prof. Manju Bansal, Director, IBAB, Prof. N. Srinivasan, Molecular Biophysics Unit, Indian Institute of Science, Mr. Shashi Kant, Hannover Medical Institute, Germany and Mr. Mohan Babu, Department of Botany, Bharathiar University for their feedback and support.

\section{References}

I. Levine AS, Kotz CM, Gosnell BA: Sugars: hedonic aspects, neuroregulation, and energy balance. Am J Clin Nutr 2003, 78(4):834S-842S.

2. Pinget M, Boullu-Sanchis S: Physiological basis of insulin secretion abnormalities. Diabetes Metab 2002, 28(6 Suppl):4S2 I-32.

3. Weihrauch MR, Diehl V, Bohlen H: Artificial sweeteners-are they potentially carcinogenic? Med Klin (Munich) 2002, 96:670-675.

4. Kanarek RB: Does sucrose or aspartame cause hyperactivity in children? Nutr Rev 1994, 52(5): I73-5.

5. Cohen S: What's the truth about the health risks of sugar substitutes such as saccharin and aspartame? Health News 200I, 7(I): 10 .

6. Nabors LO: Saccharin and aspartame: are they safe to consume during pregnancy? J Reprod Med 1988, 33(8): 102.

7. Hagiwara A, Fukushima S, Kitaori M, Shibata M, Ito N: Effects of three sweeteners on rat urinary bladder carcinogenesis initiated by N-butyl-N-(4-hydroxybutyl)-nitrosamine. Gann I984, 75(9):763-8. 
8. Nelson G, Hoon MA, Chandrashekar J, Zhang Y, Ryba NJ, Zuker CS: Mammalian sweet taste receptors. Cell 200I, 106:38I-390.

9. Margolskee RF: Molecular mechanisms of bitter and sweet taste transduction. I Biol Chem 2002, 277: I-4.

10. Li X, Staszewski L, Xu H, Durick K, Zoller M, Adler E: Human receptors for sweet and umami taste. Proc Natl Acad Sci USA 2002, 99:4692-4696.

II. Conte C, Ebeling M, Marcuz A, Nef P, Andres-Barquin PJ: Identification and characterization of human taste receptor genes belonging to the TAS2R family. Cytogenet Genome Res 2002, 98(I):45-53.

12. Nelson G, Chandrashekar J, Hoon MA, Feng L, Zhao G, Ryba NJ, Zuker CS: An amino-acid taste receptor. Nature 2002, 416(6877): 199-202.

13. Ming D, Hellekant G: Brazzein, a new high-potency thermostable sweet protein from Pentadiplandra brazzeana B. FEBS Lett 1994, 355(I): 106-8.

14. Van Der Wel H, Loeve K: Isolation and characterization of thaumatin I and II, the sweet-tasting proteins from Thaumatococcus daniellii Benth. Eur J Biochem 1972, 31:221-225.

I5. Inglett GE, May JF: Serendipity berries - source of a new intense sweetner. J Food Sci 1969, 34:408-4I I.

16. Harada S, Otani H, Maeda S, Kai Y, Kasai N, Kurihara Y: Crystallization and preliminary $X$-ray diffraction studies of curculin: $A$ new type of sweet protein having taste-modifying action. Mol Biol 1994, 238:286-287.

17. Liu X, Maeda S, Hu Z, Aiuchi T, Nakaya K, Kurihara Y: Purification, complete amino acid sequence and structural characterization of the heat-stable sweet protein, mabinlin II. Eur J Biochem 1993, 2 II (I-2):28I-7.

18. Takahashi N, Hitotsuya H, Hanzawa H, Arata $\mathrm{Y}$, Kurihara Y: Structural study of asparagine-linked oligosaccharide moiety of taste-modifying protein, miraculin. J Biol Chem 1990, 265( I 4):7793-8.

19. Faus I: Recent developments in the characterization and biotechnological production of sweet-tasting proteins. Appl Microbiol Biotechnol 2000, 53(2): |45-5|.

20. Caldwell JE, Abildgaard F, Dzakula Z, Ming D, Hellekant G, Markley JL: Solution structure of the thermostable sweet-tasting protein brazzein. Nat Struct Biol 1998, 5:427-43 I.

21. Hung LW, Kohmura M, Ariyoshi Y, Kim SH: Structural differences in $\mathrm{D}$ and $\mathrm{L}$-monellin in the crystals of racemic mixture. J Mol Biol 1999, 285:3||-32|.

22. Izawa H, Ota M, Kohmura M, Ariyoshi Y: Synthesis and characterization of the sweet protein brazzein. Biopolymers 1996, 39(I):95-101.

23. Assadi-Porter FM, Aceti DJ, Markley JL: Sweetness determinant sites of brazzein, a small, heat-stable, sweet-tasting protein. Arch Biochem Biophys 2000, 376(2):259-65.

24. Jin Z, Danilova V, Assadi-Porter FM, Aceti DJ, Markley JL, Hellekant G: Critical regions for the sweetness of brazzein. FEBS Lett 2003, 544(I-3):33-7.

25. Charron C, Giege R, Lorber B: Structure of thaumatin in a hexagonal space group: comparison of packing contacts in four crystal lattices. Acta Crystallogr D Biol Crystallogr 2004, 60(Pt I):83-9.

26. McPherson A, Weickmann J: X-ray analysis of new crystal forms of the sweet protein thaumatin. I Biomol Struct Dyn 1990 7(5): $1053-60$.

27. Kaneko R, Kitabatake N: Heat-induced formation of intermolecular disulfide linkages between thaumatin molecules that do not contain cysteine residues. J Agric Food Chem 1999, 47(1 2):4950-5.

28. Ogata C, Hatada M, Tomlinson G, Shin WC, Kim SH: Crystal structure of the intensely sweet protein monellin. Nature 1987 328(6 I 32):739-42.

29. Menco BP, Hellekant G: Ultrastructural evidence for a binding substance to the sweet-tasting protein thaumatin inside taste bud pores of rhesus monkey foliate papillae. Microsc Res Tech |993, 26(2):|33-4|.

30. Farbman Al, Ogden-Ogle CK, Hellekant G, Simmons SR, Albrecht $\mathrm{RM}, \mathrm{Van}$ Der Wel H: Labeling of sweet taste binding sites using a colloidal gold-labeled sweet protein, thaumatin. Scanning Microsc 1987, I(I):35I-7.

31. Zemanek EC, Wasserman BP: Issues and advances in the use of transgenic organisms for the production of thaumatin, the intensely sweet protein from Thaumatococcus danielli. Crit Rev Food Sci Nutr 1995, 35(5):455-66.

32. Ota M, Sawa A, Nio N, Ariyoshi Y: Enzymatic ligation for synthesis of single-chain analogue of monellin by transglutaminase. Biopolymers 1999, 50(2): 193-200.

33. Lee SY, Lee JH, Chang HJ, Cho JM, Jung JW, Lee W: Solution structure of a sweet protein single-chain monellin determined by nuclear magnetic resonance and dynamical simulated annealing calculations. Biochemistry 1999, 38(8):2340-6.

34. Hung LW, Kohmura M, Ariyoshi Y, Kim SH: Structure of an enantiomeric protein, D-monellin at I.8 A resolution. Acta Crystallogr D Biol Crystallogr 1998, 54(Pt 4):494-500.

35. Mizukoshi T, Kohmura M, Suzuki E, Ariyoshi Y: Structure and dynamic studies by NMR of the potent sweet protein monellin and a non-sweet analog. Evidence on the importance of residue AspB7 for sweet taste. FEBS Lett 1997, 413(3):409-16.

36. Kohmura $M$, Nio $N$, Ariyoshi $Y$ : Solid-phase synthesis of [AsnA16]-, [AsnA22]-, [GInA25]-, and [AsnA26]monellin, analogues of the sweet protein monellin. Biosci Biotechnol Biochem 1992, 56(3):472-6.

37. Kurihara Y: Characteristics of antisweet substances, sweet proteins, and sweetness-inducing proteins. Crit Rev Food Sci Nutr 1992, 32(3):231-52.

38. Yamashita H, Theerasilp S, Aiuchi T, Nakaya K, Nakamura Y, Kurihara $Y$ : Purification and complete amino acid sequence of a new type of sweet protein taste-modifying activity, curculin. J Biol Chem 1990, 265(26): 15770-5.

39. Yamashita H, Akabane T, Kurihara Y: Activity and stability of a new sweet protein with taste-modifying action, curculin. Chem Senses 1995, 20(2):239-43.

40. Barre A, Van Damme EJ, Peumans W], Rouge P: Curculin, a sweettasting and taste-modifying protein, is a non-functional mannose-binding lectin. Plant Mol Biol 1997, 33(4):69I-8.

4I. Harada S, Otani H, Maeda S, Kai Y, Kasai N, Kurihara Y: Crystallization and preliminary $X$-ray diffraction studies of curculin. A new type of sweet protein having taste-modifying action. J Mol Biol 1994, 238(2):286-7.

42. Guan RJ, Zheng JM, Hu Z, Wang DC: Crystallization and preliminary $X$-ray analysis of the thermostable sweet protein mabinlin II. Acta Crystallogr D Biol Crystallogr 2000, 56(Pt 7):918-9.

43. Kohmura M, Ariyoshi $Y$ : Chemical synthesis and characterization of the sweet protein mabinlin II. Biopolymers 1998, 46(4):215-23.

44. Nirasawa $S$, Liu X, Nishino T, Kurihara Y: Disulfide bridge structure of the heat-stable sweet protein mabinlin II. Biochim Biophys Acta 1993, I 202(2):277-80.

45. Nirasawa $S$, Nishino T, Katahira M, Uesugi S, Hu Z, Kurihara $Y$ : Structures of heat-stable and unstable homologues of the sweet protein mabinlin. The difference in the heat stability is due to replacement of a single amino acid residue. Eur J Biochem 1994, 223(3):989-95.

46. Theerasilp S, Hitotsuya H, Nakajo S, Nakaya K, Nakamura Y, Kurihara $Y$ : Complete amino acid sequence and structure characterization of the taste-modifying protein, miraculin. J Biol Chem 1989, 264(I 2):6655-9.

47. Gerritsen VB: The sweet side of life. Protein spotlight 200I [http:216.239.59.104/ search?q=cache:MZ3 MUgill:www.bv229.k12.ks.us/biophilia/MolecularBiologyClasProtein\%2520Software\%2520\%26\%2520Files/Proteins/ SwissPro teinSpotlights/sptlt017.pdf].

48. van der Wel H, Larson G, Hladik A, Hladik CM, Hellekant G, Glaser $D$ : Isolation and characterisation of pentadin, the sweet principle of Pentadiplandra brazzeana Baillon. Chem Senses 1989, 1 4:75-79.

49. Faus I, Sisniega H: Sweet-tasting proteins. Biopolymers (book) 8:203-220.

50. Zhao GQ, Zhang Y, Hoon MA, Chandrashekar J, Erlenbach I, Ryba NJ Zuker CS: The receptors for mammalian sweet and umami taste. Cell 2003, I I5(3):255-66.

5I. Tancredi T, Pastore A, Salvadori S, Esposito V, Temussi PA: Interaction of sweet proteins with their receptor. A conformational study of peptides corresponding to loops of brazzein, monellin and thaumatin. Eur J Biochem 2004, 27 I ( I I ):223I-40.

52. Kunishima N, Shimada Y, Tsuji Y, Sato T, Yamamoto M, Kumasaka T, Nakanishi S, Jingami H, Morikawa K: Structural basis of glutamate 
recognition by a dimeric metabotropic glutamate receptor. Nature 2000, 407:97।-977.

53. Tsuchiya D, Kunishima N, Kamiya N, Jingami H, Morikawa K: Structural views of the ligand-binding cores of a metabotropic glutamate receptor complexed with an antagonist and both glutamate and Gd ${ }^{3+}$. Proc Natl Acad Sci (USA) 2002, 99:2660-2665

54. Temussi PA: Why are sweet proteins sweet? Interaction of brazzein, monellin and thaumatin with the TIR2-TIR3 receptor. FEBS Lett 2002, 526: I-3.

55. Inoue M, Reed DR, Li X, Tordoff MG, Beauchamp GK, Bachmanov AA: Allelic Variation of the Tas/r3 Taste Receptor Gene Selectively Affects Behavioral and Neural Taste Responses to Sweeteners in the $F_{2}$ Hybrids between C57BL/6ByJ and I 29P3/J Mice. J Neurosci 2004, 24(9):2296-303.

56. Damak S, Rong M, Yasumatsu K, Kokrashvili Z, Varadarajan V, Zou S, Jiang P, Ninomiya Y, Margolskee RF: Detection of sweet and umami taste in the absence of taste receptor TIR3. Science 2003, 30I(5634):850-3. Epub 2003.

Publish with Bio Med Central and every scientist can read your work free of charge

"BioMed Central will be the most significant development for disseminating the results of biomedical research in our lifetime. "

Sir Paul Nurse, Cancer Research UK

Your research papers will be:

- available free of charge to the entire biomedical community

- peer reviewed and published immediately upon acceptance

- cited in PubMed and archived on PubMed Central

- yours - you keep the copyright

Submit your manuscript here:

http://www.biomedcentral.com/info/publishing_adv.asp 